Економічні науки: збірник наукових праџь Луцького національного технічного університету. - Серія "Регіональна економіка". - Випуск 16 (63). - Редкол.: відп. ред. д.е.н., професор Л.Л. Ковальська - Луцьк : ІВВ Луцького НТУ, 2019. -173 с.

УДК 005.334:338.45:621

Кулик Ю.М., к.е.н., асистент

Нікітін T.O.

Луцький національний технічний університет

\title{
КОМПЛЕКСНЕ ЗАСТОСУВАННЯ СУЧАСНИХ МЕТОДІВ УПРАВЛІННЯ ДЛЯ ПІДВИЩЕННЯ ЕФЕКТИВНОСТІ ДІЯЛЬНОСТІ ПІДПРИЕМСТВ ГАЛУЗІ МАШИНОБУДУВАННЯ
}

У статті розглянуто сучасні методи управління, такі як реінжиніринг, аутсорсинг та бенчмаркінг. Представлено авторське тлумачення понять, визначено переваги та недоліки їх застосування. Запропоновано комплексний підхід до їх застосування в практиці машинобудівних підприємств України.

Ключові слова: підприємство, галузь, реінжиніринг, аутсорсинг, бенчмаркінг, ефективність.

Kulik Yu., Nikitin T.

\section{COMPLEX APPLICATION OF MODERN METHODS OF MANAGEMENT IS FOR INCREASE OF EFFICIENCY OF ACTIVITY OF ENTERPRISES OF INDUSTRY OF ENGINEER}

In the modern terms of development of enterprises important is a question of improvement of production of enterprises of industry of engineer. Presently NTR plays a decision role for business. As a result, proprietors of firms and top managers constantly in the searches of the most optimum administrative decisions. One of variants of subsequent varintiv development there is the use of the newest methods of management, such as: reinzhiniring, autsorsing and benchmarking.

Reinzhiniring is an administrative model which foresees drastic alternations in the system of management, and also application of innovative technologies and computer-aided manufacturing, at the conduct of economic activity of enterprise. Autsorsing is model basis is the division of labor and narrow specialization: delegation of some functions of enterprise to other for the sake of increase of efficiency of activity. Benchmarking is based on the study of activity of competitors and introduction of the best experience in the economic activity.

Analysing advantages and lacks of management methods, can do the followings conclusions: afore-mentioned models have a row of positive aspects, however for application it is needed to determine their expedience, scale of enterprise and his possibility; also it follows to take into account negative aspects, in fact they can harm subsequent activity or, in worse-case, to result in diminishing of efficiency or to bankruptcy of enterprise. 
Економічні науки: збірник наукових праџь Луцького національного технічного університету. - Серія "Регіональна економіка". - Випуск 16 (63). - Редкол.: відп. ред. д.е.н., професор Л.Л. Ковальська - Луцьк : ІВВ Луцьккого НТУ, 2019. -173 с.

In quality of the complex going near implementacii of these approaches in practice of domestic machine-building enterprises will define the sequence of the stages; an analysis of processes is on an enterprise; estimation of activity of firm; leadthrough of reinzhiniringu, benchmarkingu and autsorsingu and working out the totals; research of experience of world companies.

Complex application of all afore-mentioned methods can be looked after in motor industry. World producers of cars of such as Ford and Porshe (VAG Group), applied in future use all afore-mentioned methods on the enterprises.

Key words: enterprise, industry, reinzhiniring, autsorsing, benchmarking, efficiency.

Кулик Ю., Никитин Т.

\section{КОМПЛЕКСНОЕ ПРИМЕНЕНИЕ СОВРЕМЕННЫХ МЕТОДОВ УПРАВЛЕНИЯ ДЛЯ ПОВЫШЕНИЯ ЭФФЕКТИВНОСТИ ДЕЯТЕЛЬНОСТИ ПРЕДПРИЯТИЙ ОТРАСЛИ МАШИНОСТРОЕНИЯ}

В статье рассмотрены современные методы управления, такие как реинжиниринг, аутсорсинг и бенчмаркинг. Представлено авторское толкование понятий, определенно преимущества и недостатки их приложения. Предложен комплексный подход к их приложению в практике машиностроительных предприятий Украины.

Ключевые слова: предприятие, отрасль, реинжиниринг, аутсорсинг, бенчмаркинг, эффективность.

Постановка проблеми у загальному вигляді та її зв'язок 3 важливими науковими та практичними завданнями. В сучасних умовах розвитку підприємств важливим є питання удосконалення виробництва підприємств галузі машинобудування. Нині НТР відіграє вирішальну роль для бізнесу. Як наслідок, власники фірм і топ менеджери постійно в пошуках найоптимальніших управлінських рішень. Одним із варіантів подальших варінтів розвитку є використання новітніх методів управління, таких як: реінжиніринг, аутсорсинг та бенчмаркінг.

Аналіз останніх досліджень, у яких започатковано вирішення проблеми. Дослідженню вищезгаданих методів було присвячено низка праць як іноземних, так і вітчизняних вчених. Зокрема тему реінжинірингу висвітлювали М. Хаммер, 
Економічні науки: збірник наукових праиь Луиького національного технічного університету. - Серія "Регіональна економіка". - Випуск 16 (63). - Редкол.: відп. ред. д.е.н., професор Л.Л. Ковальська - Луцьк : ІВВ Луиького НТУ, 2019. - 173 с.

Дж. Чампи, М. Робсон, О. Бабак, О. Пархоменко-Куцевіл, О. Єршова та ін.; аутсорсингу - Дж. Хейвуд, Д. Рігбі, Б. Білоді, О. Гусєв, Л. Покровская, Барсукова; бенчмаркінгу - Р. Кемп, Р. Рейдер, Х.Дж. Харрінгтон, Дж.С. Харрінгтон, Н. Навольська, Т. Морщенюк, С. Савельєв та ін. Однак, у цих працях не згадувалось комплексне застосування усіх цих методів, тим самим обумовивши актуальність обраної теми.

Цілі статті. Метою статті є визначення ключових передумов для застосування комплексного підходу щодо управління підприємствами галузі машинобудування з використанням сучасних методів управління.

Виклад основного матеріалу дослідження 3 повним обгрунтуванням отриманих наукових результатів. Для початку, вважаємо доцільним подати тлумачення управлінським методам:

1. реінжиніринг - це управлінська модель, яка передбачає докорінні зміни в системі менеджменту, а також застосування інноваційних технологій та автоматизація виробництва при веденні господарчої діяльності підприємства [2].

2. аутсорсинг $є$ основою моделі $\epsilon$ розподілу праці та вузької спеціалізації: делегування деяких функцій підприємства іншому задля підвищення ефективності діяльності [4].

3. бенчмаркінг базується на вивченні діяльності конкурентів та впровадження найкращого досвіду у своїй господарській діяльності [6].

Наступним етапом дослідження є визначення переваг та недоліків використання вищезгаданих методів (табл. 1).

Проаналізувавши переваги та недоліки методів управління, можемо зробити наступні висновки: вищезгадані моделі мають низку позитивних аспектів, проте для застосування потрібно визначати їхню доцільність, масштабність підприємства та його можливості; негативні аспекти також слід брати до уваги, адже вони можуть нашкодити подальшій діяльності чи, в гіршому випадку, призвести до зменшення ефективності або ж до банкрутства підприємства. 
Економічні науки: збірник наукових праџь Луцького національного технічного університету. - Серія "Регіональна економіка". - Випуск 16 (63). - Редкол.: відп. ред. д.е.н., професор Л.Л. Ковальська - Луцьк : ІВВ Луцького НТУ, 2019. -173 с.

У якості комплексного підходу до імплементації даних підходів в практику вітчизняних машинобудівних підприємств визначимо послідовність етапів.

Аналіз процесів на підприємстві.

Проведення внутрішнього дослідження усіх процесів на фірмі; дослідження зовнішнього середовища (конкуренцію на ринку).

Таблиця 1

Переваги та недоліки застосування

сучасних управлінських методів [2;3;4;6]

\begin{tabular}{|c|c|c|}
\hline Метод & Переваги & Недоліки \\
\hline реінжиніринг & $\begin{array}{l}\text { - радикальні зміни в } \\
\text { системі менеджменту } \\
\text { підприємства; } \\
\text { - збільшення } \\
\text { ефективності; } \\
\text { - вилучення } \\
\text { малоефективних ланок } \\
\text { підприємства; } \\
\text { - короткий термін } \\
\text { реалізації (6-12 місяців). }\end{array}$ & $\begin{array}{l}\text { - не всі фірми } \\
\text { готові до } \\
\text { фундаментальних } \\
\text { зрушень у системі } \\
\text { управління; } \\
\text { - недостатня } \\
\text { кількість ресурсів; } \\
\text { - брак досвіду. }\end{array}$ \\
\hline Аутсорсинг & $\begin{array}{l}\text { - скорочення } \\
\text { малоефективних } \\
\text { підрозділів підприємства; } \\
\text { - вузька спеціалізація } \\
\text { аутсорсингових компаній; } \\
\text { - відповідальність } \\
\text { аутсорсера. }\end{array}$ & $\begin{array}{l}\text { - ризик отримання } \\
\text { неякісних послуг; } \\
\text { - висока вартість; } \\
\text { - можливість } \\
\text { банкрутства } \\
\text { аутсорсера. }\end{array}$ \\
\hline Бенчмаркінг & $\begin{array}{l}\text { - підвищення } \\
\text { конкурентоспроможності; } \\
\text { - спрямованість на } \\
\text { клієнта; } \\
\text { - покращення сервісу. }\end{array}$ & $\begin{array}{l}\text { - висока вартість; } \\
\text { - недоступність } \\
\text { якісної інформації. }\end{array}$ \\
\hline
\end{tabular}


Економічні науки: збірник наукових праџь Луцького національного технічного університету. - Серія "Регіональна економіка". - Випуск 16 (63). - Редкол.: відп. ред. д.е.н., професор Л.Л. Ковальська - Луцьк : ІВВ Луцьккого НТУ, 2019. -173 с.

Відомий американський науковець М. Хаммер [3], який вперше описав реінжиніринг як модель управлінську модель, виділяє 3 типи фірм:

1. підприємство на стадії високій стадії розвитку - даний тип компаній розвивається в ногу 3 часом, вчасно реагує на зовнішнє середовище і має налагоджену систему управління.

2. підприємство з незначними проблемами - фірми даного типу - середньостатистичні гравці на ринку. Основним завданням підприємств є підвищення конкурентоздатності.

3. підприємство із великою кількістю проблем - це дає змогу оцінити на якій стадії перебуває підприємство i, що доцільно, застосовувати на даному етапі розвитку.

Оцінка діяльності фірми:

1. підприємство із великими проблемами - для даного виду підприємств, на нашу думку, доцільно застосовувати кризовий реінжиніринг чи аутсорсинг. Реінжиніринг може допомогти усунути малоефективні ланки та підвищити загальну економічну ефективність. Аутсорсинг в даному виді підприємств допоможе перевести малоефективні ланки на вузькоспеціалізовані фірми, що покращить технології і якість кінцевих продуктів чи наданих послуг.

2. підприємство має невеликі проблеми для цього типу фірм. Найдоцільнішим будуть поступові вдосконалення, тобто використання аутсорсингу та бенчмаркінгу. Перший допоможе підвищити ефективність окремих структур, а останній дасть змогу оцінити свою діяльності з боку конкурентів.

3. підприємство на високій стадії розвитку може застосовувати реінжиніринг розвитку, тобто удосконалити існуючі ланки та підвищити в рази їхню ефективність, а бенчмаркінг дасть змогу залишатися висококонкурентним підприємством, яке спрямоване на кінцевого споживача.

Проведення реінжинірингу, бенчмаркінгу та аутсорсингу й підведення підсумків - на цьому етапі потрібно визначити ефективність проведених заходів та оцінити доцільність подальшого застосування. 
Економічні науки: збірник наукових праџь Луцького національного технічного університету. - Серія "Регіональна економіка". - Випуск 16 (63). - Редкол.: відп. ред. д.е.н., професор Л.Л. Ковальська - Луцьк : ІВВ Луиького НТУ, 2019. - 173 с.

Наступний етап вивчення - дослідження досвіду світових компаній.

Застосування аналізованих методів управління має місце в світовій практиці. Реінжиніринг дає змогу значно підвищити показники ефективності та продуктивності праці на підприємстві. Аутсорсинг успішно застосовується компаніями задля підвищення якості наданих послуг та зменшення витрат на оплату праці. Бенчмаркінг - це постійний процес, який повинен відбуватися на кожному підприємстві, адже основна мета цієї моделі - це орієнтованість на кінцевого споживача та збільшення якості наданих послуг.

Комплексне застосування усіх вищезгаданих методів можна спостерігати у автомобільній промисловості. Світові виробники автомобілів таких як Ford та Porshe (VAG Group), застосовували i надалі користуються всіма вищезгаданими методами на своїх підприємствах.

- реінжиніринг дозволив компанії Ford значно зменшити кількість працівників у відділі заборгованості з 500 до 125 чол., a Porsche, за допомоги цього методу, зменшила час на виконання креслень 330 днів до 1 дня;

- модель аутсорсингу застосовують обидві компанії для закупівлі запасних частин, адже це значно підвищує їхню якість та зменшує витрати на утримання заводів, персоналу;

- бенчмаркінг застосовується 3 усіх напрямків: як для навчання персоналу, так для інженерних рішень на виробництві.

Висновки. Підсумовуючи усе вищесказане, можна зробити висновок, що в наступні роки буде посилюватися значення постійного розвитку підприємств та вузької спеціалізації. Для збереження конкурентоздатності потрібно застосовувати сучасні управлінські методи реінжинірингу, бенчмаркінгу, аутсорсингу в комплексі. Вищезгадані методи позитивно впливають на розвиток компаній, проте для їхнього застосування потрібно чимало грошових коштів, досвіду та кваліфікованого персоналу. 
Економічні науки: збірник наукових праџь Луцького національного технічного університету. - Серія "Регіональна економіка". - Випуск 16 (63). - Редкол.: відп. ред. д.е.н., професор Л.Л. Ковальська - Луцьк : ІВВ Луцького НТУ, 2019. -173 с.

1.Пархоменко-Куцевіл О.І. Сучасні тенденції розвитку реінжинірингу в системі державного управління. Ефективність державного управління. 2013. Вип 36. С. 20-26.

2.Хаммер М. Реінжиніринг корпорації : маніфест революції в бізнесі. СПб. 2000. 332 c.

3.Степанова H.I. Реінжиніринг бізнес-процесів як інструмент покращення економічного стану підприємств. 2013. № 20. С. 22-24.

4.Морщенок Т.С. Бенчмаркінг як інструмент підвищення конкурентоспроможності підприємницьких структур. Економіка і суспільство. 2017. Вип. 9. С. 533-540.

5.Навольська Н.В. Бенчмаркінг як інструмент підвищення ефективності діяльності підприємства. Економіка та управління підприємствами. 2016. Вип. 6. С. 79-82.

6.Барсукова Ю.Г., Кругліков А.М., Сдинак В.Ю. Аутсорсинг маркетингової діяльності як основа управління конкурентоздатністю підприємств в сучасних ринкових умовах. Ефективна економіка № 1 : вебсайт. URL: http://www.economy.nayka.com.ua/?op=1\&z=3722. (дата звернення 13.12.2014)

7.Як успішні компанії використовують аутсорсинг для підвищення своєї ефективності. Бізнес веб-сайт. URL: https://www.business.ua/business/5009-autsorsynh-dlia-kozhnoho. (дата звернення 22.04.2019)

8.Газуда Л.М., Салдан Т.Ю. Аутсорсинг як інструмент підвищення конкурентоспроможності підприємства. Науковий вісник Мукачівського державного університету. Сер. Економіка.. 2015. Вип. 2. С. 124-128.

9. Артеменко Л.П., Полонська Є.С. Досвід впровадження бенчмаркінгу на підприємствах України. Сучасні проблеми економіки та підприємництвво.2011. №6. С. 103-106. 